\title{
Meningococcal pneumonia: a review
}

\author{
Charles Feldman ${ }^{1 *}$ and Ronald Anderson ${ }^{2}$
}

\begin{abstract}
Background: Although Neisseria meningitidis is one of the major causes of meningitis, meningococcal pneumonia is the most common non-neurological organ disease caused by this pathogen.

Methods: We conducted a review of the literature to describe the risk factors, pathogenesis, clinical features, diagnosis, treatment and prevention of meningococcal pneumonia.

Results: Meningococcal pneumonia was first described in 1907 and during the 1918-1919 influenza pandemic large numbers of cases of meningococcal pneumonia occurred in patients following the initial viral infection. A number of publications, mainly case series or case reports, has subsequently appeared in the literature. Meningococcal pneumonia occurs mainly with serogroups Y, W-135 and B. Risk factors for meningococcal pneumonia have not been well characterised, but appear to include older age, smoking, people living in close contact (e.g. military recruits and students at university), preceding viral and bacterial infections, haematological malignancies, chronic respiratory conditions and various other non-communicable and primary and secondary immunodeficiency diseases. Primary meningococcal pneumonia occurs in 5-10\% of patients with meningococcal infection and is indistinguishable clinically from pneumonia caused by other common pathogens. Fever, chills and pleuritic chest pain are the most common symptoms, occurring in $>50 \%$ of cases. Productive sputum and dyspnoea are less common. Diagnosis of meningococcal pneumonia may be made by the isolation of the organism in sputum, blood, or normally sterile site cultures, but is likely to underestimate the frequency of meningococcal pneumonia. If validated, PCR-based techniques may be of value for diagnosis in the future. While penicillin was the treatment of choice for meningococcal infection, including pneumonia, prior to 1991, a third generation cephalosporin has been more commonly used thereafter, because of concerns of penicillin resistance. Chemoprophylaxis, using one of a number of antibiotics, has been recommended for close contacts of patients with meningococcal meningitis, and similar benefits may be seen in contacts of patients with meningococcal pneumonia. Effective vaccines are available for the prevention of infection with certain meningococcal serogroups, but this field is still evolving.
\end{abstract}

Conclusion: Meningococcal pneumonia occurs fairly frequently and should be considered as a possible cause of pneumonia, particularly in patients with specific risk factors.

Keywords: Antibiotics, Chemoprophylaxis, Diagnosis, Neisseria meningitidis, Pathogenesis, Pneumonia, Risk factors, Vaccination

\section{Introduction}

Pneumonia due to Neisseria meningitidis (meningococcus) was first reported by Jacobitz in 1907, in patients with pneumonia in whom $N$. meningitidis was isolated from sputum samples [1]. The initial cases were soldiers sharing barracks, who were probably infected through a single index patient [2]. Interestingly, even all those

\footnotetext{
*Correspondence: charles.feldman@wits.ac.za

'Department of Internal Medicine, Faculty of Health Sciences, University of the Witwatersrand, Johannesburg, South Africa

Full list of author information is available at the end of the article
}

years ago, Jacobitz had recognised that healthy individuals could harbour $N$. meningitidis in their oropharynges such that isolation of the microorganism could not provide a definitive clinical diagnosis of meningococcal pneumonia [1, 2]. During the 1918-1919 influenza pandemic a large number of cases of meningococcal pneumonia were described in patients following on the initial viral infection [3]. Since the description of these initial cases, several surveillance studies, case series, as well as a myriad of case reports have described cases of meningococcal pneumonia, occurring predominantly in 
adolescents, adults and the elderly [2]. Most recently, Vossen and colleagues reviewing the literature were able to identify 344 cases reported in the Americas, Europe, Australia and Asia between 1906 and 2015 [2]. These authors also noted that when reviewing national surveys on the incidence of invasive meningococcal disease (IMD), pneumonia was noted to be the most common non-neurological organ disease, occurring in 66 of 364 cases (17\% of cases). In this context, pneumonia associated with meningococcal disease may be primary, when it occurs alone without evidence of pre-existing meningitis or meningococcaemia [4], but can also occur in association with, or as a complication of, both those conditions and/or with other manifestations of meningococcal infection. The meningococcal pneumonia cases published in the literature include both primary and/or associated pneumonias. However, not all authors describe the cases separately, such that distinguishing true primary infections in the literature is often difficult.

\section{Neisseria meningitidis \\ The microorganism}

$N$. meningitidis (meningococcus) is a Gram-negative aerobic diplococcus. It has a typical bean or kidney shape, and is an obligate human pathogen [5-7]. The microorganism frequently colonises the oro- or nasopharynges of even healthy individuals, but can also colonise other parts of the body [7]. The microorganism grows well on chocolate and blood agar at temperatures between 35 and $37^{\circ} \mathrm{C}$ in an atmosphere of $5-10 \%$ carbon dioxide [8, 9], while confirmation of the presence of this microorganism in clinical specimens is undertaken according to the results of a series of carbohydrate fermentations [8]. The microorganism has a number of virulence factors (see below), including a polysaccharide capsule. While this capsule is important for protecting the microorganisms from complement-mediated phagocytosis and lysis, it also enables differentiation of the 13 serogroups of the microorganism, of which, serogroups A, B, C, W, $\mathrm{X}$ and $\mathrm{Y}$ are largely responsible for human disease [5-7].

\section{Epidemiology of meningococcal infection}

Although meningococcal disease is widespread globally, the epidemiology of this condition varies in different geographical regions and has evolved and changed over time [10-14]. The disease can occur as sporadic cases, outbreaks, or as large epidemics [11]. Epidemics with large numbers of infected patients occur intermittently in the sub-Saharan African region (often referred to as the "meningitis belt"), with periodicity of five to 10 years [5-7]. In countries such as Brazil, however, it tends to be endemic, with periodic occurrence of epidemics [7]. In the developed world, the infection tends to be endemic and somewhat restricted [5-7], although in countries such as the United States (US), there has been an increase in outbreaks, as well as a change in the serogroups commonly causing infection $[5,14]$.

The distribution of the different serogroups varies both temporally and geographically, which may explain the varied clinical presentations of the infection regionally and chronologically $[7,11]$. Importantly, knowledge of the distribution of serotypes in different regions is essential for the design of vaccination programs [5]. Seasonally, infections are more common in winter, or early spring. Endemic infections occur mostly in children below the age of 10 years, while during epidemic infections a wide age range of patients is infected [7]. In general, the infection is more common in men, but in patients older than 50 years, it is more common in women [7]. With respect to transmission, the development of IMD is related to the recent acquisition of a pathogenic strain by a susceptible individual, most commonly as result of close physical contact [8].

\section{Risk factors for meningococcal infection Patient risk factors}

Age is an important risk factor for meningococcal pneumonia, which occurs mostly in older individuals $>50$ years of age, and is the most common manifestation of IMD in those aged > 65 years, in contrast to meningococcal meningitis, which occurs predominantly in children and adolescents $[2,15]$. However, more recent data suggests that the age distribution of meningococcal pneumonia is bimodal, occurring before the age of 30 years and after 60 years of age [2]. Although all serogroups of the meningococcus can cause pneumonia, the less common serogroups of the pathogen are more frequently implicated as discussed below $[2,8]$.

Other risk factors for IMD include smoking, immunoglobulin and complement deficiencies, asplenia, deficiencies in mannose-binding lectin and other genetic abnormalities [2, 16, 17] and possibly human immunodeficiency virus (HIV) infection [15, 18, 19]. Additional risk factors include close contact with patients who have meningococcal infection, people living in close quarters (such as military recruits [as mentioned above], university students, and people on Hajj), as well as preceding influenza and other respiratory viral and bacterial infections including those caused by Haemophilus influenzae and Streptococcus pneumoniae [16, 17, 19, 20]. Winstaed in his series of cases with meningococcal pneumonia, collected over a 25 year period, noted concomitant viral infection, as well as underlying lymphoma, multiple myeloma, asthma, chronic obstructive pulmonary disease (COPD), insulin-dependent diabetes mellitus and other forms of diabetes mellitus, systemic lupus erythematosus, HIV infection, sickle cell anaemia, coronary artery disease/patients with coronary artery bypass graft, 
and cirrhosis among his patients [19]. These risk factors are summarised in Table 1.

\section{Specific meningococcal serogroups}

Studies have suggested that the frequency of serogroup Y, which was previously relatively uncommon in Europe, remains high or is increasing in certain regions of the continent [21], with a number of studies and case reports having indicated the association of serogroup $\mathrm{Y}$ with meningococcal pneumonia [22-26]. In England and Wales, increasing numbers of laboratory-confirmed cases of IMD caused by serogroup Y were detected between 2007 and 2009, with clonal type cc174 found to be associated with non-meningeal disease, particularly pneumonia, in the elderly ( $>65$ years) [22]. Among those infected with serogroup $Y$, the median age of onset was highest for patients with pneumonia (86.1 years [IQR 69.9-90.0] versus 42.8 [IQR 14.4-71.7]; $p<0.0001$ ). Persons with pneumonia were more likely to have underlying comorbid conditions (13/19 [68\%] versus 12/46 $[26 \%] ; p=0.001$ ), while the case fatality rate was substantially higher for pneumonia than meningitis $(9 / 19$ [47\%] versus $2 / 22$ [9\%]), septicaemia $(1 / 17$ [6\%]) or other conditions (no deaths). After adjusting for age, underlying medical conditions and pneumonia (OR 7.0; 95\%CI $1.4-36.4 ; p=0.020$ ) were found to be independently associated with death. Infections caused by serogroup Y

Table 1 Possible risk factors for invasive meningococcal disease and/or meningococcal pneumonia

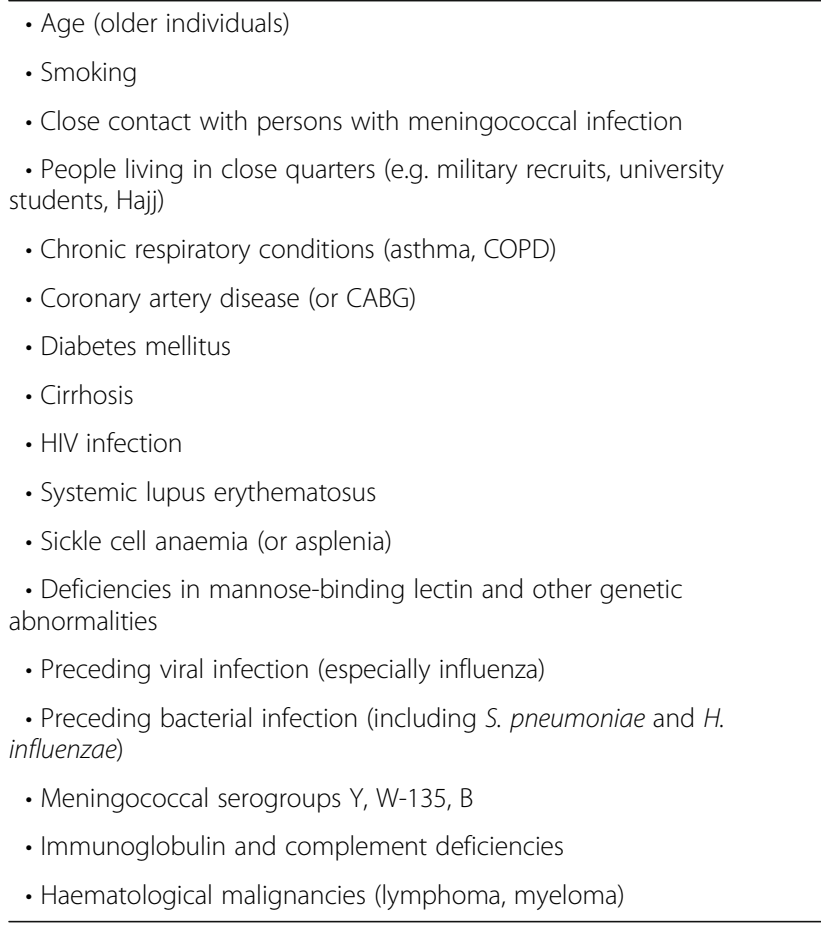

$C A B G$ coronary artery bypass graft, COPD chronic obstructive pulmonary disease, HIV human immunodeficiency virus also increased significantly in Sweden between 1995 and 2012, with one retrospective observational study of 175 patients documenting the occurrence of pneumonia in 34 (19\%) patients, either alone or associated with another focus of infection [26]. In that study, the highest mortality was for cases with bacteraemia with no known focus $(13 \%)$, while the mortality for those cases with pneumonia was $9 \%$.

A number of studies and case reports from the US has also attested to the importance of serogroup $\mathrm{Y}$ as a cause of meningococcal pneumonia, either on its own, or associated with other forms of meningococcal infection [27-29]. Additional studies in the military from the US [30-32] and Finland [33] have also documented serogroup $\mathrm{Y}$ as a cause of meningococcal pneumonia. In one series of 12 cases of primary meningococcal pneumonia reported in the US, serogroup Y infection was documented in two cases, confirmed by radiological evidence of a pneumonia and isolation of the organism on blood cultures [30]. In another such study, serogroup Y meningococcal disease occurred in 88 US Air Force recruits, of whom 68 had primary bacterial pneumonia, this being much more common than the occurrence of meningococcaemia or meningitis [31]. All cases ultimately responded well to antibiotic therapy. In the Finnish study, a fulminant case of meningococcal pneumonia complicated by sepsis, pericarditis and pleural effusion prompted the investigation of the distribution of meningococcal serogroups in nasopharyngeal cultures among the recruits from the same unit [33]. The study documented that 14 of 31 (46\%) isolates cultured were serogroup Y, isolated almost entirely from individuals that had been vaccinated against serogroups $\mathrm{A}$ and $\mathrm{C}$.

Similarly, a number of studies, mainly case reports or small case series, have also noted that serogroup W-135 is associated with pneumonia, particularly in older patients [34-41]. The latter study, a nationwide retrospective study, which analysed epidemiological data from 115 patients with laboratory-confirmed meningococcal disease found that serogroup W-135 accounted for $26 \%$ of all cases, and that most of the patients $(76.7 \%)$ were older than 20 years of age [41]. No differences were found in the presenting features other than a higher prevalence of pneumonia in those with W-135 infection (23.8\% versus $1.5 \%$; OR 20.6; $95 \%$ CI $2.3-189.0 ; p=$ 0.003 ) [41]. Lastly, a case report from the US described a 16-year old student with clinical signs and radiological findings compatible with pneumonia, which on sputum culture revealed a serogroup B meningococcus [42].

\section{Pathogenesis \\ Colonisation of the oro-nasopharynx by Neisseria meningitidis}

As stated by Laver et al., Neisseria meningitidis "is one of a handful of potential pathogens that can silently 
colonise the oro-nasopharynx, which represents its sole biological niche" [43]. The estimated frequencies of oronasopharyngeal colonisation by this exclusively human pathogen are around $10-35 \%$ and $5.9 \%$ of adults and children, respectively [44]. As mentioned above, colonisation rates are significantly increased by both active cigarette smoking and exposure to sidestream tobacco smoke [45-47], probably as a consequence of smokemediated suppression of the innate and adaptive immune mechanisms of the respiratory tract $[48,49]$. Cigarette smoke also affects respiratory pathogens directly, resulting in augmentation of bacterial virulence mechanisms, particularly increased biofilm formation [50-52].

The most important virulence factors of the meningococcus with respect to oro-nasopharyngeal colonisation include the immunoglobulin A1 (IgA1) protease and the anti-phagocytic polysaccharide capsule, as well as a series of epithelium-binding bacterial adhesins. The IgA1 protease, which is most important in previously exposed individuals, is a site-specific serine protease. It cleaves the antibody molecule at the hinge region, separating the Fab and Fc regions, preventing expulsion of the pathogen by mucociliary clearance, favouring attachment to respiratory epithelium [53]. It has also been proposed that the meningococcal IgA1 protease may have a broader than previously realised substrate specificity, encompassing other immune-associated proteins such as the type II tumour necrosis factor receptor [54] and human lysosome-associated membrane protein [55].

Notwithstanding its primary role in counteracting phagocytosis, the polysaccharide capsule of the meningococcus repels mucus, also hindering mucociliary clearance [56]. The capsular polysaccharides of four of the six major serogroups associated with invasive disease, specifically serogroups $\mathrm{B}, \mathrm{C}, \mathrm{W}$, and $\mathrm{Y}$ are composed of sialic acid derivatives. The capsules of the other invasive groups, serogroups $\mathrm{A}$ and $\mathrm{X}$, are composed of repeating units of $\mathrm{O}$-acetylated $(\alpha 1 \rightarrow 6)$-linked $\mathrm{N}$-acetyl-D-mannosamine-1-phosphate [57] and $(\alpha-1 \rightarrow 4) \mathrm{N}$-acetylglucosamine 1-phosphate [58], respectively. Sialic acids are also present in the cell surface glycoconjugates of eukaryotic cells and protect not only host cells, but also those meningococcal serogroups with sialic acid -containing capsules, against attack by the alternative pathway of complement via binding of the major regulatory protein factor $\mathrm{H}(\mathrm{fH})$, which is achieved via inhibition of C3 convertase and inactivation of C3b [59].

The next step in colonisation of the nasopharynx by the meningococcus involves attachment of the pathogen to respiratory epithelium, a process that necessitates a reduction in capsule size in order to expose underlying protein adhesins. Initial contact between the pathogen and epithelium is mediated by Type IV pili; these are complex structures comprised of over twenty proteins, which contribute to the formation of the fully functional adhesin, with the PilE and PilV components playing prominent roles in adhesion $[60,61]$. The identity of the epithelial cell receptor targeted by the Type IV pilus has, however, remained elusive. A possible contender identified in brain endothelial cells is CD147 (also known as EMMPRIN or extracellular matrix metalloproteinase inducer) [62]. Although also expressed on epithelial cells, the involvement of CD147 in Type IV pilus-mediated attachment of the meningococcus to respiratory epithelium remains uncertain.

Type IV pilus-mediated epithelial attachment enables subsequent firmer binding mediated by the meningococcal opacity proteins, Opa and Opc [60]. Opa targets the carcinoembryonic antigen cell adhesion molecule (CEACAM) receptor on epithelium, mostly the CEACAM1 receptor [63], while Opc has been reported to bind to activated vitronectin on endothelial cells [64], also present on epithelium. Various minor adhesins, such as NadA (Neisseria adhesin A) also contribute to epithelial attachment and these have been described in detail elsewhere [60].

Having reached the potentially hostile environment of the nasopharynx, the meningococcus utilises several strategies to ensure persistence. As demonstrated in experimental systems, these are firstly, infection of epithelial cells by the pathogen and intracellular survival, which necessitates restoration of the encapsulated phenotype [65]. Secondly, the meningococcus also persists in the nasopharynx via encasement in biofilm [66]. In this setting, extracellular deoxyribonucleic acid (DNA) represents a major structural component of meningococcal biofilms, promoting binding of surface proteins and other extracellular polymers to form effective multicellular biofilms [66].

\section{Translocation of the meningococcus to the lower airways}

Notwithstanding dissemination to the lungs via the bloodstream or by person-to-person inhalation of contaminated aerosol droplets, microaspiration of biofilmencased meningococci resident in the nasopharynx appears to represent the most probable mechanism of translocation of the meningococcus to the lower airways [2]. In this latter context, it is noteworthy that recent influenza virus infection in particular, as well as preceding pharyngitis, have both been linked to development of meningococcal pneumonia [67-69].

Given the seemingly lesser virulence of the meningococcus relative to that of exotoxin-producing bacterial respiratory pathogens such as Streptococcus pneumoniae, Staphylococcus aureus and Pseudomonas aeruginosa, the meningococcus may require a trigger to achieve full pathogenicity. In this context, the influenza virus is a 
particularly effective partner with respect to facilitating development of meningococcal pneumonia. This has been convincingly demonstrated in a murine model of experimental infection in which initial infection with influenza A virus was found to predispose for subsequent development of meningococcal bacteraemia [70]. Mechanisms by which preceding influenza virus infection may trigger development of meningococcal pneumonia include the following: i) inhibition of the mucociliary escalator [71]; ii) in the case of strains of the meningococcus belonging to sialic acid-containing capsular polysaccharide groups, viral neuraminidase mediates cleavage of capsular sialic acid, exposing underlying bacterial adhesins, facilitating adhesion to respiratory epithelium [61]; and iii) viral infection-associated elevated levels of pulmonary interferon- $\gamma$ [70], which induce downregulation of expression of the alveolar macrophage class A scavenger, MARCO (macrophage receptor with collagenous structure) [72], an opsonin, which avidly binds unopsonised $N$. meningitidis via interaction with unidentified protein ligands [73].

Once established in the lower airways, the meningococcus utilises an array of virulence factors, which enable the pathogen to suppress or divert pulmonary host defences, resulting in establishment of severe infection.

\section{Virulence mechanisms of the meningococcus}

Notwithstanding the polysaccharide capsule and the IgA1 protease, the meningococcus possesses a range of additional virulence factors, which enable survival and proliferation of the pathogen in the lower airways. These include:

- Factor H-binding protein (fHbp), a 27-kDa surfaceexposed lipoprotein, long recognised as being a key virulence factor of the meningococcus, is expressed by the majority of virulent strains of the pathogen [74]. With respect to its role in bacterial virulence, fHbp binds the major regulator of the alternative pathway of complement activation, $\mathrm{fH}$, to the bacterial surface, thereby conferring protection against complement-mediated opsonophagocytosis and bacterial killing [74]. In addition, Porin A, one of two meningococcal porins, which play crucial roles in ion exchange, has also been reported to attenuate activation of the classical complement pathway via interaction with $\mathrm{C} 4 \mathrm{~b}$-binding protein [75];

- Lipooligosaccharide endotoxin (LOS) is also a key virulence factor of the meningococcus. It is located in the outer membrane of the meningococcus and consists of a hydrophobic lipid A component linked to an outer hydrophilic oligosaccharide. As with other bacterial endotoxins, LOS possesses potent pro-inflammatory activities mediated primarily via interaction with the Toll-like receptor 4/MD2 complex on cells of the innate immune system, resulting in initiation of the MyD88-dependent signalling cascade and resultant production of a range of inflammatory cytokines/chemokines [76, 77]. Although potentially protective, the intensity of the LOS-activated inflammatory response is likely to result in lung damage, as well as dysfunction of pulmonary adaptive immune mechanisms. In addition, release of LOS contained in extracellular vesicles [78] may divert meningococcus-targeted immune mechanisms, while exacerbating harmful inflammatory responses. Moreover, binding of spontaneously released meningococcal outer membrane vesicles has been reported to prevent ensnarement of intact organisms by neutrophil extracellular traps in vitro [79];

- Modification of capsular size is also a strategy used by the meningococcus to evade adaptive immune mechanisms. In this context, it is noteworthy that the capsular polysaccharides of serogroups A, B, C, $\mathrm{W}$ and $\mathrm{Y}$ have been reported to interfere with activation of the classical complement pathway by preventing deposition of $\mathrm{C} 4 \mathrm{~b}$ following activation of complement by anti-capsular polysaccharide IgG and IgM antibodies, as well as via antagonism of binding of IgM antibodies targeted against LOS [80]. In addition, the weak immunogenicity of the capsular polysaccharide of serogroup B meningococcus also contributes to the virulence of this serogroup of the pathogen.

The events involved in oro-nasopharyngeal colonisation and invasion of the lower airways by the meningococcus are summarised in Fig. 1.

\section{Clinical presentation}

While meningococcal meningitis is the most common manifestation of meningococcal disease, primary pneumonia occurs in approximately $5-10 \%$ of patients with meningococcal disease $[6,7]$. The clinical presentation of meningococcal pneumonia is indistinguishable from pneumonia caused by other infectious pathogens and while symptoms such as fever, chills and pleuritic chest pain are common, occurring in more than $50 \%$ of cases, productive cough and shortness of breath are less common [2]. A rash may occur in patients with pneumonia and associated sepsis, but meningococcaemia is a rare accompaniment of pneumonia [2]. Neither laboratory findings nor radiological features allow differentiation from other causes of pneumonia [2]. 


\section{Exposure to the meningococcus}

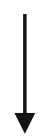

Oro-nasopharyngeal colonisation mediated by:

- Polysaccharide capsule

- $\lg \mathrm{A} 1$ protease

- Epithelial adhesins

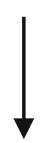

\section{Oro-nasopharyngeal persistence} mediated by:

- Capsule-dependent intra-epithelial invasion

- Biofilm formation

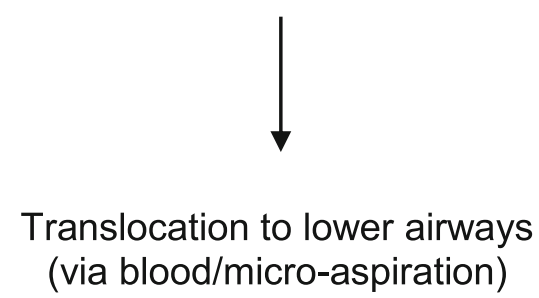

(via blood/micro-aspiration)
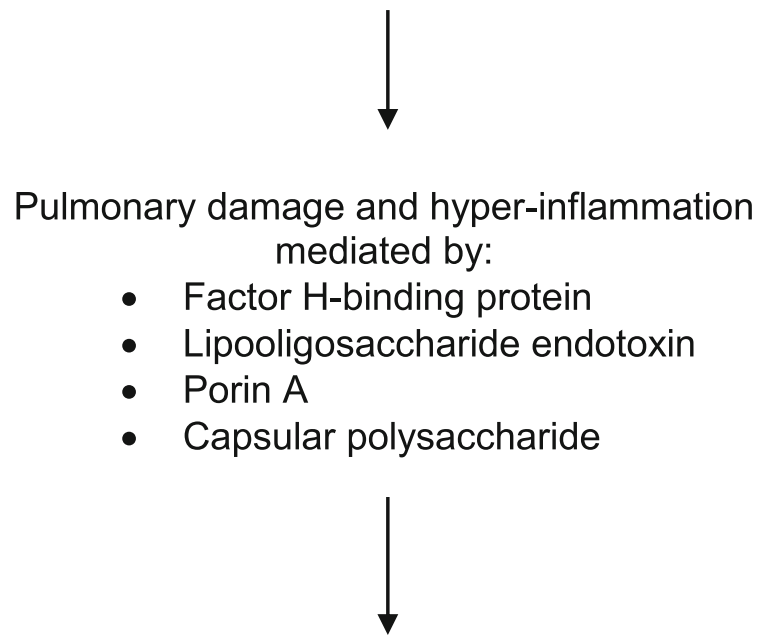

\section{Meningococcal pneumonia}

Fig. 1 Possible stages in the pathogenesis of meningococcal pneumonia
Case series - IMD

A number of case series has been reported over the years, describing either meningococcal disease, of which some patients had pneumonia [15, 81, 82], or specifically meningococcal pneumonia $[19,83]$. Stephens and colleagues undertook a prospective, population-based surveillance of adult patients in Atlanta, US between 1 December 1988 and 30 November 1993 during which $N$. meningitidis was isolated from normally sterile sites [15]. Overall, 14/44 adults (32\%) had pneumonia, sinusitis or tracheobronchitis as the likely source of bacteraemia, with pneumonia occurring in 10/44 (23\%) cases. Seven of the 10 cases with pneumonia were $\geq 50$ years of age, while no pneumonias occurred in the 18-24year old group. Serogroups Y, W-135 and B were the most common causes of pneumonia, as described elsewhere. Another surveillance study of IMD was undertaken in Dallas County, US, between 1992 and 1997 [81]. Overall, 151 patients were identified. Older patients $(>50$ years) were more likely to have pneumonia (32\% versus $4 \%$; $p=0.0001)$ and less likely to have meningitis ( $\mathrm{p}=$ 0.0001) when compared with younger patients. Among patients with pneumonia, there was a trend for more infections caused by serogroup Y. In addition, Hazarika and colleagues reported an outbreak of IMD in children in India between January 2008 and June 2009 [82]. Pneumonia occurred in $6.4 \%$ of cases.

\section{Case series - meningococcal pneumonia}

Putsch and colleagues studied hospitalised patients with pneumonia in Cleveland, US, during two time-periods in 1968, taking sputum or tracheal aspirates, which were cultured to optimise isolation of $N$. meningitidis, as well as acute and convalescent sera [83]. To determine carrier rates of the pathogen, throat cultures and sera were obtained from asymptomatic outpatients and sputum cultures from hospitalised patients without acute respiratory infection. The carrier rates were 7 and 13\% in the initial and second periods, respectively. Overall, 47 patients, with a median age of 46 years, had acute pneumonia with the meningococcus isolated from sputum culture in $14(30 \%)$ of cases. In addition, the meningococcus was isolated from sputum culture in seven of the 23 cases (30\%) with respiratory infection other than pneumonia, but not from any of the patients without respiratory infection. The predominant serogroup in both patients with and without pneumonia was serogroup B. Winstaed and colleagues reviewed 58 cases of meningococcal pneumonia of all ages, 50 of which had previously been described in the literature, with eight new cases of their own added [19]. The median age was 57.5 years and 27 (52.9\%) were males. Overall, 29 cases had prior underlying conditions (5 had other recent or concomitant infections, 4 patients had diabetes mellitus and 4 
COPD, three patients were on corticosteroids [2 with asthma and 1 with systemic lupus erythematosus], 3 patients had myeloma or lymphoma and 2 cases had HIV infection). There were other, less common, associated medical conditions. Fever and chills and associated pleuritic chest pain occurred in $>50 \%$ cases, whereas productive cough and shortness of breath were less common. Various radiological findings were noted, including pleural effusion in six patients (13.3\%). The most common serogroup isolated was Y (44\%) followed by W135 (19.2\%). A variety of antibiotic therapies was used. Complications included septic shock in two patients, while lung abscess, exudative pleural effusion, respiratory arrest, pericarditis and drug-induced neutropenia occurred in one patient each. The average age of the five (8.62\%) patients who died was almost 20 years greater than that of the cases that survived.

\section{Case reports - meningococcal pneumonia}

A myriad of case reports of patients of all ages with meningococcal pneumonia has been published over the years from various regions of the world, including the US [4, 20, 42, 84-88], Europe [24, 89-97], the United Kingdom [98, 99], Russia [100], Japan [101-103], Taiwan [104], Australia [105], South America [106, 107] and Oman [69]. The characteristics of the patients with meningococcal pneumonia were similar to those described elsewhere in this review.

\section{Other respiratory syndromes}

Meningococcal infections have also been described as causing respiratory symptoms or conditions other than community-acquired pneumonia. One case study described a patient with meningococcaemia who presented initially as a non-specific "flu-like" syndrome, before significantly deteriorating [108]. In fact, presentation with upper respiratory tract symptoms, such as coryza and pharyngitis, together with fever and other symptoms, is a common early manifestation of meningitis, especially in children, and is followed subsequently by the classical features of meningitis or sepsis [6]. One study in a large district general hospital in the Netherlands reported 46 isolates of $N$. meningitidis cultured from the respiratory secretions of 44 patients, of whom one had pneumonia, 19 had acute respiratory infections and 18 had acute purulent exacerbations of chronic bronchitis [109]. The remaining cases, all of whom had purulent sputum, had a variety of symptoms. $N$. meningitidis has also been isolated in other studies from patients with acute and chronic bronchitis [110, 111], or other types of nonpneumonia lower respiratory tract infections [112]. Furthermore, $N$. meningitidis has also been documented as a cause of nosocomial pneumonia [113-116].
Among the respiratory complications that have been noted in patients with meningococcal pneumonia are cavitating lung infection [117], pleural effusion [118, $119]$, and empyema [120, 121], the latter case caused by a penicillin-resistant $N$. meningitidis.

\section{Laboratory diagnosis}

Traditional microbiological culture techniques based on isolation of the meningococcus from saliva or sterile body fluids, usually blood or pleural fluid, remain the cornerstone of laboratory diagnosis of IMD [122]. It is very likely, however, that meningococcal pneumonia is underdiagnosed for several reasons: i) the pneumonia is often clinically indistinct from other pneumonias, such as pneumococcal pneumonias; ii) sputum is unreliable in diagnosis since it is difficult to differentiate asymptomatic oropharyngeal carriers from cases of pneumonia due to the meningococcus; and iii) blood cultures are relatively insensitive [2]. In the latter context, blood culture positivity rates in the setting of diagnosis of meningococcal pneumonia are variable, ranging from 6 to $79.3 \%$ $[19,31]$. If validated and available, microbiological culture techniques may be supported by PCR-based approaches, including multiplex polymerase chain reaction (PCR) for simultaneous detection of meningococcal, pneumococcal and Haemophilus influenzae infection [122]. Latex agglutination tests for detection of meningococcal group-specific capsular polysaccharides in urine and cerebrospinal fluid, but not blood, are also available. However, these are of limited diagnostic application due to a high frequency of false-positive results, as well as failure to detect serogroup B meningococcal infection, which is common in many countries [122].

\section{Treatment of meningococcal pneumonia}

Prior to 1991, penicillin was the treatment of choice for meningococcal infections [2]. However, with the emergence of penicillin-resistant strains in 1991 [123], in the setting of the high mortality associated with IMD, the empiric treatment recommendation was changed to a third generation cephalosporin [2]. Although not commonly done, should the microorganism be found to be sensitive to penicillin, therapy of IMD with high-dose penicillin may be considered. Concerningly, isolates of meningococci with decreased susceptibility to penicillin, as well as emerging resistance to other antibiotics, have been recognised in Spain, Europe, South Africa, the US, Canada and Brazil [123-131], with the latter study also reporting resistance of the meningococcus to ciprofloxacin. Alternative drug choices include meropenem (unavailability of a third generation cephalosporin), chloramphenicol (for severe beta-lactam allergy), aztreonam (if chloramphenicol is unavailable in the case of severe beta-lactam allergy), or a fluoroquinolone, such as 
moxifloxacin (currently restricted in the US, due to consideration of meningococcal fluoroquinolone resistance and lack of controlled trials in IMD) [7].

Although the optimal regimen for the treatment of meningococcal pneumonia per se has not been determined, it seems likely to be similar to that of IMD [2]. In fact, it has been noted that most cases of meningococcal pneumonia received penicillin before 1991 and that most received a cephalosporin after that date [19].

Corticosteroids have been used as adjunctive therapy in patients with meningitis, but their benefit appears to be evident in pneumococcal, rather than meningococcal, meningitis. Accordingly, these agents are not usually recommended in the clinical setting of meningococcal disease [2, 132]. Although there has been emerging evidence for the benefit of adjunctive corticosteroid therapy in patients with severe community-acquired pneumonia, there are no reports on the possible benefits of corticosteroids in severe meningococcal pneumonia [2].

\section{Prevention \\ Chemoprophylaxis}

Chemoprophylaxis to eliminate nasopharyngeal carriage is recommended in close contacts of cases with meningococcal infection, in whom the risk of acquiring the infection is considerably elevated (400 to 800 -fold higher than in the general population) [17]. Antibiotics that have been used include rifampicin, ceftriaxone, azithromycin and fluoroquinolones, although concerns about antibiotic resistance surround the use of rifampicin and the fluoroquinolones $[5,7,17]$. As indicated elsewhere, nosocomial cases of meningococcal pneumonia have been described, some of which appear to have developed following contact with patients who have meningococcal pneumonia [114, 115]. While the recommendations for prophylaxis are based on studies of contact with cases of meningitis, the epidemiology of meningococcal infection suggests that similar benefits may also be seen with chemoprophylaxis in the setting of contact with meningococcal pneumonia cases [8].

\section{Immunization}

Prevention of severe meningococcal disease is largely based on the immunoprophylaxis of meningococcal meningitis. As with prevention of invasive pneumococcal disease, two types of meningococcal capsular-based polysaccharides vaccines exist. Firstly, vaccines which consist solely of capsular polysaccharides derived from four of the major disease-causing serogroups of the meningococcus, specifically A, C, Y and W-135, and, secondly, conjugate vaccines in which the capsular polysaccharides are chemically linked to a suitable, immunogenic protein carrier, usually diphtheria toxoid, CRM197
[133]. According to the World Health Organization (WHO), meningococcal polysaccharide vaccines are bivalent (serogroups $A$ and $C$ ), trivalent (serogroups $A, C$ and W-135), or tetravalent (A, C, Y, W-135) [133]. As with pneumococcal polysaccharide vaccines, however, meningococcal purified capsular polysaccharide vaccines are also weakly immunogenic, being ineffective in the very young and failing to induce herd protection. Indeed, Sanofi-Pasteur recently announced discontinuation of production Menomune ${ }^{\circ}$, which is a tetravalent polysaccharide vaccine, approved in 1981 by the Food and Drug Administration (FDA) of the US for prevention of invasive meningococcal disease (serogroups A, C, Y and W135 ) in high-risk individuals aged 2 years and older.

Currently two main types of meningococcal tetravalent conjugate vaccine exist. These are Menactra ${ }^{\circ}$ and Men$\mathrm{veo}^{\circ}$ licensed in the US in 2005 and 2010 respectively. Both contain purified meningococcal polysaccharides (A, C, Y and W-135) conjugated to CRM197. A similar vaccine, Nimenrix ${ }^{\circ}$, containing the same capsular polysaccharides conjugated to tetanus toxoid as protein carrier, is available outside the US. Relative to those vaccines containing purified polysaccharides only, the conjugate vaccines have improved immunogenicity, are suitable for use in very young children, prevent carriage and induce herd protection [133]. However, lack of coverage against serotype $B$ remains a limitation of these vaccines.

To address this issue, two novel, capsular polysaccharide-free, protein-based vaccines have been developed, which specifically target serogroup B $N$. meningitidis. These are Trumenba ${ }^{\circ}$ (MenB-FHbp) licensed for use in the US in 2014 and Bexsero ${ }^{\circ}$ (4CMenB) licensed in the US, Canada, Europe and Australia, countries and regions in which invasive disease caused by $N$. meningitidis serogroup B remains a significant problem. Trumenba ${ }^{\circ}$, manufactured by Wyeth Pharmaceuticals Inc., is primarily recommended for immunisation of at-risk individuals aged $\geq 10-25$ years and consists of the two recombinant variants of the meningococcal surface protein, fHBp $[134,135]$. Bexsero ${ }^{\circ}$, manufactured by GlaxoSmithKline plc, is a more complex vaccine, which is comprised of three recombinant meningococcal serogroup $B$ proteins combined with outer membrane vesicles derived from group B strain NZ98/254 [136]. Of the constituent proteins, two of these viz. fHbp and Neisseria heparin-binding protein (NHBA), are recombinant fusion proteins, while the third is the intact recombinant protein adhesin, NadA. The vesicles derived from strain NZ98/254 are enriched with a fourth immunogenic protein, PorA [136]. As with Trumenba ${ }^{\circ}$, Bexsero ${ }^{\circ}$ is also recommended to protect those "at risk" individuals aged $\geq 10-25$ years and has demonstrated protective efficacy ranging from around $64-78 \%$ in adolescents, as well as infants, having been introduced into the national 
Table 2 Types and applications of meningococcal vaccines

\begin{tabular}{|c|c|c|c|}
\hline Type & Vaccine antigen & Application & Refs \\
\hline $\begin{array}{l}\text { Purified capsular polysaccharide-based } \\
\text { vaccines (not available for serogroup B) }\end{array}$ & $\begin{array}{l}\text { i) Serogroups } A, C \text { (bivalent) } \\
\text { ii) Serogroups } A, C, W-135 \text { (trivalent) } \\
\text { iii) Serogroups } A, C, Y, W-135 \text { (tetravalent) }\end{array}$ & $\begin{array}{l}\text { Weakly immunogenic; recommended for high-risk } \\
\text { persons aged } \geq 2 \text { years }\end{array}$ & [133] \\
\hline $\begin{array}{l}\text { Tetravalent capsular polysaccharide conjugate } \\
\text { vaccines. Two types available: Menactra }^{\oplus} \text { and } \\
\text { Menveo }^{\circledR}\end{array}$ & $\begin{array}{l}\text { Serogroups } A, C, Y, W-135 \text { covered by } \\
\text { both vaccines }\end{array}$ & $\begin{array}{l}\text { Improved immunogenicity; suitable for } \\
\text { immunization of young children; prevent } \\
\text { nasopharyngeal carriage; induce herd protection }\end{array}$ & [134] \\
\hline $\begin{array}{l}\text { Protein-based, capsular polysaccharide-free } \\
\text { vaccines targeting serogroup B. Two types } \\
\text { available: Trumenba }{ }^{\oplus} \text { and Bexsero }{ }^{\oplus}\end{array}$ & $\begin{array}{l}\text { i) Two recombinant variants of } \\
\text { serogroup B fHbp (Trumenba }{ }^{\oplus} \text { ) } \\
\text { ii) Three recombinant serogroup B } \\
\text { proteins (fHbp; NHBA; NadA)* and } \\
\text { vesicle-packaged Porin A (Bexero }{ }^{\oplus} \text { ) }\end{array}$ & $\begin{array}{l}\text { High-risk persons aged } \geq 10-25 \text { years } \\
\text { High-risk persons aged } \geq 10-25 \text { years and young } \\
\text { children }\end{array}$ & $\begin{array}{l}{[134-} \\
140]\end{array}$ \\
\hline
\end{tabular}

${ }^{*} \mathrm{fHbp}=$ factor $\mathrm{H}$-binding protein; $\mathrm{NHBA}=$ Neisseria heparin-binding protein; $\mathrm{NadA}=$ Neisseria adhesin $\mathrm{A}$

immunisation programmes of the United Kingdom and Republic of Ireland [137-140].

With respect to novel potential vaccine candidate antigens, the IgA1 protease of the meningococcus, which shares a limited number of common epitopes with that of its pneumococcal counterpart, has shown promise in providing cross-protection against both bacterial pathogens in pre-clinical evaluation [141].

Table 2 describes the types and applications of meningococcal vaccines.

\section{Mortality}

Meningococcal pneumonia appears to have a higher case-fatality rate than meningococcal meningitis $(16 \%$ and $9-14 \%$, respectively), with age (highest in patients > 65 years of age), specific serogroups (higher among serogroup $\mathrm{W}$ than serogroup $\mathrm{B}$ strains), and underlying disease, being important risk factors, much like other lower respiratory tract infections [2].

\section{Conclusions}

The current review highlights the risk factors, pathogenesis, clinical features, diagnosis, treatment and prevention of meningococcal pneumonia. While many of these aspects have not been as well characterised as they have been for cases with meningococcal meningitis/invasive meningococcal infection, in general, they appear to be similar. Primary meningococcal pneumonia occurs in approximately $5-10 \%$ of patients with meningococcal disease and has identical clinical features to that of pneumonia caused by the other, more common pneumonia pathogens, including the pneumococcus. However, the diagnosis is most likely underestimated as a positive sputum is unreliable as it cannot differentiate asymptomatic colonisation from invasive infection, while blood cultures have varying sensitivity. The mortality of meningococcal pneumonia is higher than that for meningitis, with age (highest in the elderly), specific serogroups (higher among serogroup W than serogroup B strains), and underlying disease, being important risk factors. Current meningococcal vaccines do not provide coverage against all of the major disease-causing serogroups. In this context, innovation is needed with respect to development of vaccines, which provide serogroup-independent coverage.

\section{Abbreviations \\ CD147: Extracellular matrix metalloproteinase inducer (also abbreviated to EMMPRIN); CEACAM: Carcinoembryonic antigen cell adhesion molecule; COPD : Chronic obstructive pulmonary disease; CRM197: Non-toxic mutant of diphtheria toxin used as a carrier protein for polysaccharide vaccines; DNA: Deoxyribonucleic acid; FDA: Food and Drug Administration; FHbp: Factor H-binding protein; HIV: Human immunodeficiency virus; IgA1: Immunoglobulin A1; IMD: Invasive meningococcal disease; LOS: Lipooligosaccharide endotoxin; MARCO: Macrophage receptor with collagenous structure; MBL: Mannose-binding lectin; NadA: Neisseria adhesin A; NHBA: Neisseria heparin-binding protein; PCR: Polymerase chain reaction; US: United States of America; WHO: World Health Organization}

\section{Acknowledgements}

Charles Feldman is supported by the National Research Foundation of South Africa.

\section{Authors' contributions}

The authors contributed equally in the planning, literature review, writing and finalising the manuscript.All authors read and approved the final manuscript.

\section{Funding}

No funding.

Availability of data and materials

Data in the manuscript is derived from a literature review.

Ethics approval and consent to participate

Ethics approval not required as this was a literature review.

\section{Consent for publication}

No consent needed for publication.

\section{Competing interests}

The authors declare that they have no competing interests.

\section{Author details}

'Department of Internal Medicine, Faculty of Health Sciences, University of the Witwatersrand, Johannesburg, South Africa. ${ }^{2}$ Department of Immunology and Institute for Cellular and Molecular Medicine, Faculty of Health Sciences, University of Pretoria, Pretoria, South Africa. 
Received: 4 March 2019 Accepted: 7 August 2019

\section{Published online: 25 August 2019}

\section{References}

1. Jacobitz H. Der Diplococcus meningitidis cerebrospinalis als erreger von Krankheiten de lunge und bronchien. Z Hyg Infectionskr. 1907;56:175-92.

2. Vossen M, Mitteregger D, Steininger C. Meningococcal pneumonia. Vaccine. 2016;34(37):4364-70. PMID: 27443594. https://doi.org/10.1016/j.vaccine.2016, 07.013.

3. Holm MI, Davison WC. Meningococcus pneumonia: the occurrence of postinfluenzal pneumonia in which Diplococcus intracellularis meningitidis was isolated. Bull Johns Hopkins Hosp. 1919;30:324.

4. Darnell JC, Brandt MJ. Primary meningococcal pneumonia: a report of three cases. J Indiana State Med Assoc. 1981;74(12):794-8 PMID: 6801145.

5. Rosenstein NE, Perkins BA, Stephens DS, Popovic T, Hudhes JM. Meningococcal disease. N Engl J Med. 2001;344(18):1378-88. PMID: 11333996. https://doi.org/10.1056/NEJM200105033441807.

6. Pace D, Pollard AJ. Meningococcal disease: clinical presentation and sequelae. Vaccine. 2012;30(Suppl 2):B3-9. PMID: 22607896. https://doi.org/1 0.1016/j.vaccine.2011.12.062.

7. Batista RS, Gomes AP, Gazineo JLD, Miguel PSB, Santana LA, Oliveira L, et al. Meningococcal disease, a clinical and epidemiological review. Asian Pac J Trop Med. 2017;10(11):1019-29. PMID: 29203096. https://doi.org/10.1016/j. apjtm.2017.10.004

8. Naheed N, Alam M, Lutwick LI. Gram-negative diplococcal respiratory infections. Curr Infect Dis Rep. 2003;5(3):238-45 PMID: 12760822. https://link. springer.com/article/10.1007/s11908-003-0079-6.

9. Rouphael NG, Stephens DS. Neisseria meningitidis: biology, microbiology, and epidemiology. Methods Mol Biol. 2012;799:1-20. PMID: 21993636. https://doi.org/10.1007/978-1-61779-346-2_1.

10. Rosenstein NE, Perkins BA, Stephens DS, Lefkowitz L, Cartter ML, Danila R, et al. The changing epidemiology of meningococcal disease in the United States, 1992-1996. J Infect Dis. 1999;180(6):1894-901. PMID: 10558946. https://doi.org/10.1086/315158.

11. Harrison LH, Trotter CL, Ramsay ME. Global epidemiology of meningococcal disease. Vaccine. 2009;27(Suppl 2):B51-63. PMID: 19477562. https://doi.org/1 0.1016/j.vaccine.2009.04.063.

12. Harrison LH. The epidemiology of meningococcal disease in the United States. Clin Infect Dis. 2010;50(Suppl 2):S37-44. PMID: 20144015. https://doi. org/10.1086/648963.

13. Cohn AC, MacNeil JR, Harrison LH, Hatcher C, Theodore J, Schmidt M, et al. Changes in Neisseria meningitidis disease epidemiology in the United States, 1998-2007: implications for prevention of meningococcal disease. Clin Infect Dis. 2010;50(2):184-91. PMID: 20001736. https://doi.org/10.1086/649209.

14. Mbaeyi SA, Blain A, Whaley MJ, Wang X, Cohn AC, MacNeil JR. Epidemiology of meningococcal disease outbreaks in the United States, 2009-2013. Clin Infect Dis. 2019;68(4):580-5. PMID: 29982382. https://doi. org/10.1093/cid/ciy548.

15. Stephens DS, Hajjeh RA, Baughman WS, Harvey RC, Wenger JD, Farley MM Sporadic meningococcal disease in adults: results of a 5-year populationbased study. Ann Intern Med. 1995;123(12):937-40. PMID: 7486489. https:// doi.org/10.7326/0003-4819-123-12-199512150-00007.

16. Morar R, Feldman C. Meningococcal pneumonia. South Afr J Epidemiol Infect. 2005;20(1):6-8.

17. Stephens DS. Conquering the meningococcus. FEMS Microbiol Rev. 2007;31(1): 3-14. PMID: 17233633. https://doi.org/10.1111/j.1574-6976.2006.00051.x.

18. Nitta AT, Douglas JM, Arakere G, Ebens JB. Disseminated meningococcal infection in HIV-seropositive patients. AIDS. 1993;7(1):87-90 PMID: 8442922.

19. Winstead JM, McKinsey DS, Tasker S, De Groote MA, Baddour LM. Meningococcal pneumonia: characterization and review of cases seen over the past 25 years. Clin Infect Dis. 2000;30(1):87-94. PMID: 10619738. https:// doi.org/10.1086/313617.

20. Galpin JE, Chow AW, Yosuikawa TT, Guze LB. Meningococcal pneumonia. Am J Med Sci. 1975:269(2):247-50 PMID: 807105

21. Bröker M, Emoner S, Fazio C, Jacobsson S, Koliou M, Kuusi M, et al. Meningococcal serogroup $Y$ disease in Europe: continuation of high importance in some European regions in 2013. Hum Vaccin Immunother. 2015;11(9):2281-6. PMID: 26036710. https://doi.org/10.1080/21645515.2015.1 051276

22. Ladhani SN, Lucidarme J, Newbold LS, Gray SJ, Carr AD, Findlow J, et al. Invasive meningococcal capsular group Y disease, England and Wales, 2007-
2009. Emerg Infect Dis. 2012;18(1):63-70. PMID: 22261040. https://doi.org/1 0.3201/eid1801.110901

23. Chan BKY, Kudsk-Iversen S, Balaguruswamy S, Purewal TS. A complicated simple fall - an atypical case of serogroup $Y$ meningococcal pneumonia with secondary septicaemia and literature review. BMJ Case Rep. 2012;2012: bcr1120115095. PMID: 22604203. https://doi.org/10.1136/bcr.11.2011.5095.

24. Romero-Gomez MP, Rentero Z, Pano JR, Mingorance J. Bacteraemic pneumonia caused by Neisseria meningitidis serogroup Y. Respir Med Case Rep. 2012:5:23-4. PMID: 26057210. https://doi.org/10.1016/j.rmedc.2011.11.005.

25. Pérez J, Gutiérrez A, Ezpeleta C, Cisterna R. Pneumonia due to Neisseria meningitidis serogroup Y. Enferm Infecc Microbiol Clin. 2003;21(5):278 PMID: 12732123. Article in Spanish.

26. Säll O, Stenmark B, Glimåker M, Jacobsson S, Mölling P, Olcén P, et al. Clinical presentation of invasive disease caused by Neisseria meningitidis serogroup $Y$ in Sweden, 1995-2012. Epidemiol Infect. 2017;145(10):2137-43. PMID: 28478773. https://doi.org/10.1017/S0950268817000929.

27. Hersh JH, Gold R, Lepow ML. Meningococcal group Y pneumonia in an adolescent female. Pediatrics. 1979;64(2):222-4 PMID: 112573.

28. Hanson MF, Lawson A. Isolation of a group $Y$ meningococcus from a patient with pneumonia. J Inf. 1985;10(1):76-7. PMID: 3920328. https://doi. org/10.1016/S0163-4453(85)80016-5 .

29. Racoosin JA, Whitney CG, Conover CS, Diaz PS. Serogroup Y meningococcal disease in Chicago, 1991-1997. JAMA. 1998;280(24):2094-8. PMID: 9875877. https://doi.org/10.1001/jama.280.24.2094.

30. Smilack JD. Group-Y meningococcal disease. Twelve cases at an army training center. Ann Intern Med. 1974;81(6):740-5. PMID: 4215351. https:// doi.org/10.7326/0003-4819-81-6-740.

31. Koppes GM, Ellenbogen C, Gebhart RJ. Group Y meningococcal disease in United States air force recruits. Am J Med. 1977;62(5):661-6. PMID: 404877 https://doi.org/10.1016/0002-9343(77)90867-1.

32. Haburchak DR. Sporadic military meningococcal disease: a diversity of presentations. South Med J. 1981;74(2):153-6 PMID: 6781070

33. Nikoskelainen J, Leino A, Lähtönen E, Kalliomäki JL, Toivanen A. Is groupspecific meningococcal vaccination resulting in epidemics caused by other groups of virulent meningococci? Lancet. 1978;2(8086):403-5. PMID: 79765. https://doi.org/10.1016/S0140-6736(78)91869-X.

34. Hammerschlag MR. Infections in children due to Neisseria meningitidis serogroup 135. J Pediatr. 1978;92(3):503. PMID: 416192. https://doi.org/10.1 016/50022-3476(78)80459-4.

35. Brandstetter RD, Blair RJ, Roberts RB. Neisseria meningitidis serogroup W 135 disease in adults. JAMA. 1981;246(18):2060-1. PMID: 6793741. https://doi. org/10.1001/jama.1981.03320180052031.

36. Richter J. Pneumonia caused by Neisseria meningitidis, serogroup 135. Can Med Assoc J. 1981;124(2):127 PMID: 6780180.

37. Witt D, Olans RN. Bacteremic W-135 meningococcal pneumonia. Am Rev Respir Dis. 1982;125(2):255-7. PMID: 6802047. https://doi.org/10.1164/arrd.1982.125.2.255.

38. Weightman NC, Johnstone DJ. Three cases of pneumonia due to Neisseria meningitidis, including serogroup W135. Eur J Clin Microbiol Infect Dis. 1999; 18(6):456-8 PMID: 10442430

39. Vienne P, Ducos-Galand M, Guiyoule A, Pires R, Giorgini D, Taha M-K, et al. The role of particular strains of Neisseria meningitidis in meningococcal arthritis, pericarditis, and pneumonia. Clin Infect Dis. 2003;37(12):1639-42. PMID: 14689345. https://doi.org/10.1086/379719.

40. Seiberras S, Fiurmaux S. Pneumonia due to Neisseria meningitidis W135. Med Mal Infect. 2010;40(6):366-7. https://doi.org/10.1016/j.medmal.2009.10.007 PMID: 19959310. Article in French.

41. Wang JL, Liu DP, Yen JJ, Yu CJ, Liu HC, Lin CY, et al. Clinical features and outcome of sporadic serogroup W135 disease Taiwan. BMC Infect Dis. 2006; 6:7. PMID: 16420709. https://doi.org/10.1186/1471-2334-6-7.

42. Paine TF, Garrard CL Jr, Walker PJ. Meningococcal pneumonia. Arch Intern Med. 1967;119(1):111-2. PMID: 6015829. https://doi.org/10.1001/archinte.196 7.00290190159017

43. Laver JR, Hughes SE, Read RC. Neisserial molecular adaptations to the nasopharyngeal niche. Adv Microb Physiol. 2015;66:323-55. PMID: 26210107. https://doi.org/10.1016/bs.ampbs.2015.05.001.

44. Uberos J, Molina-Oya M, Martinez-Serrano S, Fernández-López L. Surface adhesion and host response as pathogenicity factors of Neisseria meningitidis. World J Clin Infect Dis. 2015;5(2):37-43. https://doi.org/10.5495/wjcid.v5.i2.37.

45. Stuart JM, Cartwright KA, Robinson PM, Noah ND. Effect of smoking on meningococcal carriage. Lancet. 1989;2(8665):723-5. PMID: 2570968. https:// doi.org/10.1016/S0140-6736(89)90781-2. 
46. Caugant DA, Høiby EA, Magnus P, Scheel O, Hoel T, Bjune G, et al. Asymptomatic carriage of Neisseria meningitidis in a randomly sampled population. J Clin Microbiol. 1994;32(2):323-30 PMID: 8150942.

47. Fischer M, Hedberg K, Cardosi P, Plikaytis BD, Hoesly FC, Steingart KR, et al. Tobacco smoke as a risk factor for meningococcal disease. Pediatr Infect Dis J. 1997;16(10):979-83 PMID: 9380476.

48. Arcavi L, Benowitz NL. Cigarette smoking and infection. Arch Intern Med. 2004;164(20):2206-16. PMID: 15534156. https://doi.org/10.1001/ archinte.164.20.2206

49. Feldman C, Anderson R. Cigarette smoking and mechanisms of susceptibility to infections of the respiratory tract and other organ systems. J Inf. 2013;67(3):169-84. PMID: 23707875. https://doi.org/10.1016/j.jinf.2013. 05.004

50. Goldstein-Daruech N, Cope EK, Zhao KQ, Vukovic K, Kofonow JM, Doghramji $L$, et al. Tobacco smoke mediated induction of sinonasal microbial biofilms. PLoS One. 2011;6(1):e15700. PMID: 21253587. https://doi.org/10.1371/journal. pone.0015700

51. Mutepe ND, Cockeran R, Steel HC, Theron AJ, Mitchell TJ, Feldman C, et al. Effects of cigarette smoke condensate on pneumococcal biofilm formation and pneumolysin. Eur Respir J. 2013;41(2):392-5. PMID: 22743667. https:// doi.org/10.1183/09031936.00213211

52. Cockeran R, Herbert JA, Mitchell TJ, Dix-Peek T, Dickens C, Anderson R, et al. Exposure of a $23 \mathrm{~F}$ serotype strain of Streptococcus pneumoniae to cigarette smoke condensate is associated with selective upregulation of genes encoding the two-component regulatory system 11 (TCS11). Biomed Res Int. 2014;2014:976347. PMID: 25013815. https://doi.org/10.1155/2014/976347.

53. Vitovski S, Sayers JR. Relaxed cleavage specificity of an immunoglobulin A1 protease from Neisseria meningitidis. Infect Immun. 2007;75(6):2875-85. PMID: 17353288. https://doi.org/10.1128/IAl.01671-06.

54. Beck SC, Meyer TF. IgA1 protease from Neisseria gonorrhoeae inhibits TNFalpha-mediated apoptosis of human monocytic cells. FEBS Lett. 2000; 472(2-3):287-92. PMID: 10788628. https://doi.org/10.1016/S0014-5793 (00)01478-2

55. Ayala P, Lin L, Hopper S, Fukuda M, So M. Infection of epithelial cells by pathogenic neisseriae reduces the levels of multiple lysosomal constituents. Infect Immun. 1998;66(10):5001-7 PMID: 9746610.

56. Siegel SJ, Weiser JN. Mechanisms of bacterial colonization of the respiratory tract. Annu Rev Microbiol. 2015;69:425-44. PMID: 26488280. https://doi.org/1 0.1146/annurev-micro-091014-104209.

57. Harrison OB, Claus H, Jiang Y, Bennett JS, Bratcher HB, Jolley KA, et al. Description and nomenclature of Neisseria meningitidis capsule locus. Emerg Infect Dis. 2013:19(4):566-73. PMID: 23628376. https://doi.org/10.3201/eid1 904.111799.

58. Tzeng Y-L, Thomas J, Stephens DS. Regulation of capsule in Neisseria meningitidis. Crit Rev Microbiol. 2016;42(5):759-72. PMID: 26089023. https:// doi.org/10.3109/1040841X.2015.1022507

59. Blaum BS, Hannan JP, Herbert AP, Kavanagh D, Uhrín D, Stehle T. Structural basis for sialic acid-mediated self-recognition by complement factor $\mathrm{H}$. Nat Chem Biol. 2015;11(1):77-82. PMID: 25402769. https://doi.org/10.1038/ nchembio.1696.

60. Pizza M, Rappuoli R. Neisseria meningitidis: pathogenesis and immunity. Curr Opin Microbiol. 2015;23:68-72. PMID: 25461575. https://doi.org/10.1016/j. mib.2014.11.006.

61. Rameix-Welti MA, Zarantonelli ML, Giorgini D, Ruckly C, Marasescu M, van der Werf $\mathrm{S}$, et al. Influenza A virus neuraminidase enhances meningococcal adhesion to epithelial cells through interaction with sialic acid-containing meningococcal capsules. Infect Immun. 2009;77(9):3588-95. PMID: 19528219. https://doi.org/10.1128/IAl.00155-09 .

62. Bernard SC, Simpson N, Join-Lambert O, Federici C, Laran-Chich MP, Maïssa $\mathrm{N}$, et al. Pathogenic Neisseria meningitidis utilizes CD147 for vascular colonization. Nat Med. 2014;20(7):725-31. PMID: 24880614. https://doi.org/1 0.1038/nm.3563.

63. Virji M. The structural basis of CEACAM-receptor targeting by neisserial opa proteins: response. Trends Microbiol. 2000;8(6):260-1. PMID: 10838581. https://doi.org/10.1016/S0966-842X(00)01772-8.

64. Sa E, Cunha C, Griffiths NJ, Virji M. Neisseria meningitidis Opc invasin binds to the sulphated tyrosines of activated vitronectin to attach to and invade human brain endothelial cells. PLoS Pathog. 2010;6(5):e1000911. PMID: 20502634. https://doi.org/10.1371/journal.ppat.1000911.

65. Spinosa MR, Progida C, Talà A, Cogli L, Alifano P, Bucci C. The Neisseria meningitidis capsule is important for intracellular survival in human cells.
Infect Immun. 2007;75(7):3594-603. PMID: 17470547. https://doi.org/10.112 8/IAl.01945-06.

66. Arenas J, Tommassen J. Meningococcal biofilm formation: let's stick together. Trends Microbiol. 2017;25(2):113-24. PMID: 27712951. https://doi.org/10.1016/j.tim.2016.09.005.

67. Young LS, LaForce FM, Head JJ, Feeley JC, Bennett JV. A simultaneous outbreak of meningococcal and influenza infections. N Engl J Med. 1972;287(1):5-9. PMID: 4623954. https://doi.org/10.1056/NEJM1972 07062870102

68. Jacobs JH, Viboud C, Tchetgen ET, Schwartz J, Steiner C, Simonsen L, et al. The association of meningococcal disease with influenza in the United States, 1989-2009. PLoS One. 2014;9(9):e107486. 25265409. https://doi.org/10.1371/journal.pone.0107486.

69. Al Alawi AM. Meningococcal pneumonia in a young healthy male. Case Rep Infect Dis. 2018;2018:2179097. PMID: 30225154. https://doi.org/10.1155/201 8/2179097.

70. Alonso JM, Guiyoule A, Zarantonelli ML, Ramisse F, Pires R, Antignac $A$, et al. A model of meningococcal bacteremia after respiratory superinfection in influenza A virus-infected mice. FEMS Microbiol Lett. 2003;222(1):99-106. PMID: 12757952. https://doi.org/10.1016/S0378-1 097(03)00252-0

71. Wu NH, Yang W, Beineke A, Dijkman R, Matrosovich M, Baumgärtner W, et al. The differentiated airway epithelium infected by influenza viruses maintains the barrier function despite a dramatic loss of ciliated cells. Sci Rep. 2016;6:39668. PMID: 28004801. https://doi.org/10.1038/srep39668.

72. Sun K, Metzger DW. Inhibition of pulmonary antibacterial defense by interferon-gamma during recovery from influenza infection. Nat Med. 2008; 14(5):558-64. PMID: 18438414. https://doi.org/10.1038/nm1765.

73. Peiser L, Makepeace K, Plüddemann A, Savino S, Wright JC, Pizza M, et al. Identification of Neisseria meningitidis nonlipopolysaccharide ligands for class A macrophage scavenger receptor by using a novel assay. Infect Immun. 2006;74(9):5191-9. PMID: 16926412. https://doi.org/10.1128/IAI. 00124-06

74. Agarwal S, Vasudhev S, DeOliveira RB, Ram S. Inhibition of the classical pathway of complement by meningococcal capsular polysaccharides. J Immunol. 2014;193(4):1855-63. PMID: 25015832. https://doi.org/10.4049/ jimmunol.1303177.

75. Biagini M, Spinsanti M, De Angelis G, Tomei S, Ferlenghi I, Scarselli M, et al. Expression of factor $\mathrm{H}$ binding protein in meningococcal strains can vary at least 15-fold and is genetically determined. Proc Natl Acad Sci U S A. 2016; 113(10):2714-9. PMID: 26888286. https://doi.org/10.1073/pnas.1521142113.

76. Ngampasutadol J, Ram S, Blom AM, Jarva H, Jerse AE, Lien E, et al. Human C4b-binding protein selectively interacts with Neisseria gonorrhoeae and results in species-specific infection. Proc Natl Acad Sci U S A. 2005;102(47): 17142-7. PMID: 16275906. https://doi.org/10.1073/pnas.0506471102.

77. Zarantonelli ML, Huerre M, Taha MK, Alonso JM. Differential role of lipooligosaccharide of Neisseria meningitidis in virulence and inflammatory response during respiratory infection in mice. Infect Immun. 2006;74(10): 5506-12. PMID: 16988225. https://doi.org/10.1128/IAl.00655-06.

78. Park BS, Song DH, Kim HM, Choi BS, Lee H, Lee JO. The structural basis of lipopolysaccharide recognition by the TLR4-MD-2 complex. Nature. 2009; 458(7242):1191-5. PMID: 19252480. https://doi.org/10.1038/nature07830.

79. Gill S, Catchpole R, Forterre P. Extracellular membrane vesicles (EVs) in the three domains of life and beyond. FEMS Microbiol Rev. 2019;43(3):273-303. PMID: 30476045. https://doi.org/10.1093/femsre/fuy042.

80. Lappann M, Danhof S, Guenther F, Olivares-Florez S, Mordhorst IL, Vogel U. In vitro resistance mechanisms of Neisseria meningitidis against neutrophil extracellular traps. Mol Microbiol. 2013;89(3):433-49. PMID: 23750848. https://doi.org/10.1111/mmi.12288.

81. Pastor P, Medley FB, Murphy TV. Meningococcal disease in Dallas County, Texas: results of a six-year population-based study. Pediatr Infect Dis J. 2000;19(4):324-8 PMID: 10783023.

82. Hazarika RD, Deka NM, Khyriem AB, Lyngdoh WV, Barman H, Duwarah SG, et al. Invasive meningococcal infection: analysis of 110 cases from a tertiary care Centre in north East India. Indian J Pediatr. 2013;80(5):359-64. PMID: 22821284. https://doi.org/10.1007/s12098-012-0855-0.

83. Putsch RW, Hamilton JD, Wolinksy E. Neisseria meningitidis, a respiratory pathogen? J Infect Dis. 1970;121(1):48-54 PMID: 4983357.

84. Ball JH, Young DA. Primary meningococcal pneumonia. Am Rev Respir Dis. 1974;109(4):480-3. PMID: 4206071. https://doi.org/10.1164/arrd.1974.1 09.4.480. 
85. Irwin RS, Woelk WK, Coudon WL III. Primary meningococcal pneumonia. Ann Intern Med. 1975;82(4):493-8. PMID: 164144. https://doi.org/10.7326/ 0003-4819-82-4-493.

86. Baltimore RS, Hammerschlag M. Meningococcal bacteremia: clinical and serologic studies of infants with mild illness. Am J Dis Child. 1077;131(9): 1001-4. PMID: 409280. https://doi.org/10.1001/archpedi.1977.0212022006 7011.

87. Reddy TS, Smith D, Roy TM. Primary meningococcal pneumonia in elderly patients. Am J Med Sci. 2000;319(4):255-7. PMID: 10768612. https://doi.org/1 0.1016/S0002-9629(15)40739-6.

88. Walayat S, Hussain N, Malik AH, Vazquez-Melendez E, Aulakh BS, Lynch T. Invasive meningococcal disease without meningitis: a forgotten diagnosis. Int Med Case Rep J. 2018;11:87-90. PMID: 29695936. https://doi.org/10.2147/ IMCRJ.S154807.

89. Llorens-Terol J, Martinez-Roig A, Mur A. Pneumonia associated with meningococcal bacteremia and/or meningitis. Helv Paediatr Acta. 1984:39(2):187-92 PMID: 6543842

90. Naya Manchado J, Sanjuan Portugal F, Gascón Pelegrin JM. Community-acquired pneumonia due to Neisseria meningitidis in a healthy adult. Arch Bronconeumol. 1994;30(3):175 PMID: 8186915. Article in Spanish.

91. Hastert F, Moscariello A, Arendt V, Beissel J, Pesch C, Delagardelle C. Meningococcal pneumopathy. Bull Soc Sci Med Grand Duche Luxemb. 1994;131(1):13-6 PMID: 8050115. Article in French.

92. Bourlaud I, Bodin J, d'Arlhac M. Meningococcal pneumonia. Rev Pneumol Clin. 1995;51(2):90-2 PMID: 7569567. Article in French.

93. Royo-Villanova C, Cepeda JM, Navarro V. Neisseria meningitidis pneumoniae in 47 year old woman with systemic lupus. Enferm Infecc Microbiol Clin. 2001;19(4):188-9. https://doi.org/10.1016/S0213-005X(01)72607-9 PMID: 11333613. Article in Spanish.

94. Guignard S, Manceron V, Pouchot J, Mortier E, Vinceneux P. Extra-meningeal meningococcal infection: report of 14 cases. Rev Med Interne. 2004;25(1):37. https://doi.org/10.1016/S0248-8663(03)00255-8 PMID: 14736555. Article in French.

95. Fernádez-Pozuelo C, Sánchez-Castañón J, Aguadero-Acera V, Baena-Ferrer IM. Pneumonia by Neisseria meningitidis: a case report. Rev Esp Quimioter. 2014;27(2):132-3 PMID: 24940897. Article in Spanish.

96. Riis $\AA$ G, Berg $\AA$. A young man with respiratory infection and facial rash. Tidsskr Nor Laegeforen. 2017;137(21) 10.404s/tidsskr.17.0139. PMID: 29135167. Article in English, Norwegian.

97. Famularo G, Sordillo P, Stasolla A, Parisi MG. A 58-year old woman with pneumonia and gram-negative diplococci. Chest. 2017;152(4):e95-7. PMID: 28991556. https://doi.org/10.1016/j.chest.2017.05.037.

98. Jones EM, Brown NM, Harvey JE, Reeves DS, MacGowan AP. Three cases of meningococcal pneumonia. Thorax. 1997;52(10):927-9. PMID: 9404384 https://doi.org/10.1136/thx.52.10.927.

99. Allan RC, Moghal M, Wijesuriya V, Melzer M. University-acquired pneumonia. Lancet Infect Dis. 2006;6(3):184. PMID: 16500601. https://doi.org/10.1016/S14 73-3099(06)70416-9.

100. Pokrovskiǐ VI, Goncharova EN, Ostrovskiǐ NN, Semina NA, Konovalova OV. Meningococcal pneumonia. Sov Med. 1979;(9):16-9 PMID: 505143. Article in Russian.

101. Ootaki M, Tabeta $H$, Suzuki Y. Bilateral meningococcal pneumonia in a young Japanese woman. Nihon Kyobu Shikkan Gakkai Zasshi. 1996;34(10): 1121-4 PMID: 8953907. Article in Japanese.

102. Shiraishi M, Seki I, Andou H, Nakazawa A, Imaki S, Nagashima J, et al. A case of sepsis by Neisseria meningitidis beginning with pneumonia during a trip abroad. Kansenshogaku Zasshi. 2001;75(8):692-5 PMID: 11558132. Article in Japanese.

103. Hirai J, Kinjo T, Tome T, Hagihara M, Sakanashi D, Nakamura H, et al. Meningococcal pneumonia in Japan: a case report and literature review. J Infect Chemother. 2016;22(12):833-6. PMID: 27591787. https://doi.org/10.1 016/j.jiac.2016.07.014.

104. Tsai WC. Meningococcal pneumonia: a case report. J Microbiol Immunol Infect. 1998;31(4):253-6 PMID: 10496168

105. Goldwater PN, Rice MS. Primary meningococcal pneumonia in a nineteenmonth-old child. Pediatr Infect Dis J. 1995;14(2):155-6 PMID: 7746703.

106. Borba MGS, Oliveira MC, João GAP, Fernandes M, Silva FM, Fragoso S, et al. Invasive meningococcal disease with pericarditis and pneumonia: a rare presentation in childhood. ID Cases. 2016:4:41-2. PMID: 27077027. https:// doi.org/10.1016/j.idcr.2016.01.005.
107. Yubini MC, Contreras C, Diaz G, Cerda MA, Guiñez D, Rogers N, et al. Neisseria meningitidis pneumonia. A case report. Rev Med Chil. 2018;146(2): 249-53. https://doi.org/10.4067/s0034-98872018000200249 PMID: 29999162. Article in Spanish.

108. Watts PJ, Fazel N, Scherbak D. Meningococcemia masquerading as a nonspecific flu-like syndrome. Case Rep Crit Care. 2018;2018:2097824. PMID: 30519492. https://doi.org/10.1155/2018/2097824.

109. Davies BI, Spanjaard L, Dankert J. Meningococcal chest infections in a general hospital. Eur J Clin Microbiol Infect Dis. 1991;10(5):399-404 PMID: 1908379.

110. Fritsche $D$, Dahn $R$, Rathenberg R. Detection of meningococci in the sputum of bronchitis patients (author's transl). Infection. 1977;5(3):195-6 PMID: 914365. Article in German.

111. Ferrer Marcellés A, Andonegui Navarro M, Falcó Ferrer V, Osset Lladonosa J, Beltrán Beltrán M, Fernández PF. Neisseria meningitidis: isolation from low respiratory tract secretions of adult patients. Rev Clin Esp. 1996;196(11):7416 PMID: 9132837 . Article in Spanish.

112. Legaria MC, Chadarevian M, Regueira M, Corso A, Hoffman M. Nonpneumonia lower respiratory infection by Neisseria meningitides. Enferm Infecc Microbiol Clin. 1996;14(8):508-9 PMID: 9011216. Article in Spanish.

113. Barnes RV, Dopp AC, Gelberg HJ, Silva J Jr. Neisseria meningitidis: a cause of nosocomial pneumonia. Am Rev Respir Dis. 1975;111(2):229-31. PMID: 803357. https://doi.org/10.1164/arrd.1975.111.2.229.

114. Cohen MS, Steere AC, Baltimore R, von Graevenitz A, Pantelick E, Camp B, et al. Possible nosocomial transmission of group Y Neisseria meningitidis among oncology patients. Ann Intern Med. 1979;91(1):7-12. PMID: 464460. https://doi.org/10.7326/0003-4819-91-1-7.

115. Rose HD, Lenz IE, Sheth NK. Meningococcal pneumonia. A source of nosocomial infection. Arch Intern Med. 1981;141(5):575-7. PMID: 6784686. https://doi.org/10.1001/archinte.1981.00340050027009.

116. Nicolás-Sánchez FJ, Gázquez I, Vives M, Rubio M. Nosocomial pneumonia caused by Neisseria meningitidis. Diagnosis by aspiration transthoracic puncture. Enferm Infecc Microbiol Clin. 1995;13(4):265-6 PMID: 7779888. Article in Spanish.

117. Arrate C, Jiménez ML, Aguilar R, González A, Ancochea J. Cavitated lung pneumonia due to meningococcus. An Med Interna. 1994;11(2):86-8 PMID: 8193241. Article in Spanish.

118. Brick IB. Meningococcal pneumonia; report of two cases with meningococcal effusion in one. N Engl J Med. 1948;238(9):289-91. PMID: 18900496. https://doi.org/10.1056/NEJM194802262380903.

119. Burns JL. Primary meningococcal pneumonia diagnosed by pleural fluid culture. Am J Dis Child. 1986;140(3):188 PMID: 3946339.

120. Sacks HS. Meningococcal pneumonia and empyema. Am J Med. 1986;80: 290-1. PMID: 3080881. https://doi.org/10.1016/0002-9343(86)90024-0.

121. Glikman D, Matushek SM, Kahana MD, Daum RS. Pneumonia and empyema caused by penicillin-resistant Neisseria meningitidis: a case report and literature review. Pediatrics. 2006;117(5):e1061-6. PMID: 16606681. https:// doi.org/10.1542/peds.2005-1994.

122. Apicella M. Diagnosis of meningococcal infection. UpToDate 2019. Last updated: Aug 14, 2018. Available from: https://www.uptodate.com/ contents/diagnosis-of-meningococcal-infection. Accessed 4 Feb 2019.

123. Jackson LA, Tenover FC. Baker C, Plikaytis BD, Reeves MW, Stocker SA et al. prevalence of Neisseria meningitidis relatively resistant to penicillin in the United States, 1991. Meningococcal disease study group. J Infect Dis. 1994; 169(2):438-41. PMID: 8106779.

124. Woods CR, Smith AL, Wasilauskas BL, Campos J, Givner LB. Invasive disease caused by Neisseria meningitidis relatively resistant to penicillin in North Carolina. J Infect Dis. 1994;170(2):453-6 PMID: 8035036.

125. Oppenheim BA. Antibiotic resistance in Neisseria meningitidis. Clin Infect Dis. 1997;24(Suppl 1):S98-101 PMID: 8994787.

126. Vázquez JA, Enriquez R, Abad R, Alcalá B, Salcedo C, Arreaza L. Antibiotic resistant meningococci in Europe: any need to act? FEMS Microbiol Rev. 2007;31(1):64-70. PMID: 17147690. https://doi.org/10.1111/j.1574-6976.2006. 00049.x.

127. Panã M, Ghitã M, Levenet I, Nica M, Botea S, Osz T. The in vitro susceptibility to 7 antibiotics of Neisseria meningitidis strains isolated last years in Romania. Roum Arch Microbiol Immunol. 2009;68(1):38-43. PMID: 19507626.

128. Mounchetrou NNjoya I, Deghmane A, Taha M, Isnard H, Parent du Chatelet I. A cluster of meningococcal disease caused by rifampicin-resistant C meningcococci in France, April 2012. Euro Surveill. 2012;17(34):20254 PMID: 22939210. 
129. Tóth Á, Berta B, Tirczka T, Jekkel C, Ábrahám A, Prohászka Z, et al. First description of a rifampicin-resistant Neisseria meningitidis sergroup $Y$ strain causing recurrent invasive meningococcal disease in Hungary. Acta Microbiol Immunol Hung. 2017;64(1):1-7. PMID: 28220707. https://doi.org/1 0.1556/030.64.2017.006

130. Gorla MC, Cassiolato AP, Pinhata JMW, de Moraes C, Corso A, Gagetti P, et al. Emergence of resistance to ciprofloxacin in Neisseria meningitidis in Brazil. J Med Microbiol. 2018;67(3):286-8. PMID: 29458676. https://doi.org/10.1099/ jmm.0.000685.

131. Gorla MC, Pinhata JMW, Dias UJ, de Moraes C, Lemos AP. Surveillance of antimicrobial resistance in Neisseria meningitidis strains isolated from invasive cases in Brazil from 2009 to 2016. J Med Microbiol. 2018;67(6):7506. PMID: 29717974. https://doi.org/10.1099/jmm.0.000743.

132. De Gans J. Van de Beek D; European dexamethasone in adulthood bacterial meningitis study investigators. Dexamethasone in adults with bacterial meningitis. N Engl J Med. 2002;347(20):1549-56. PMID: 12432041. https:// doi.org/10.1056/NEJMoa021334.

133. World Health Organization (WHO). Meningococcal meningitis. 2018. Available from: https:/www.who.int/news-room/fact-sheets/detail/ meningococcal-meningitis. Accessed 25 Jan 2019.

134. Apicella M. Meningococcal vaccines. UpToDate 2019. Last updated: Mar 22, 2019. Available from: https://www.uptodate.com/contents/meningococcalvaccines. Accessed: 3 July 2019

135. Shirley M, Taha MK. MenB-FHbp meningococcal group B vaccine (Trumenba ${ }^{\oplus}$ : a review in active immunization in individuals aged $\geq 10$ years. Drugs. 2018;78(2):257-68. PMID: 29380290. https://doi.org/10.1007/s4 0265-018-0869-7.

136. Donnelly J, Medini D, Boccadifuoco G, Biolchi A, Ward J, Frasch C, et al. Qualitative and quantitative assessment of meningococcal antigens to evaluate the potential strain coverage of protein-based vaccines. Proc Nat Acad Sci U S A. 2010;107(45):19490-5. PMID: 20962280. https://doi.org/10.1 073/pnas.1013758107.

137. Banzhoff A. Multicomponent meningococcal B vaccination (4CMenB) of adolescents and college students in the United States. Ther Adv Vaccines. 2017:5(1):3-14. PMID: 28344804. https://doi.org/10.1177/2051013616681365.

138. Simões MJ, Bettencourt C, De Paola R, Giuliani M, Pizza M, Moschioni M, et al. Predicted strain coverage of a meningococcal multicomponent vaccine (4CMenB) in Portugal. PLoS One. 2017;12(5):e0176177. 28459837. https://doi. org/10.1371/journal.pone.0176177.

139. Parikh SR, Newbold L, Slater S, Stella M, Moschioni M, Lucidarme J, et al. Meningococcal serogroup B strain coverage of the multicomponent $4 C M e n B$ vaccine with corresponding regional distribution and clinical characteristics in England, Wales, and Northern Ireland, 2007-08 and 201415: a qualitative and quantitative assessment. Lancet Infect Dis. 2017;17(7): 754-62. PMID: 28366725. https://doi.org/10.1016/S1473-3099(17)30170-6.

140. Mulhall RM, Bennett D, Cunney R, Borrow R, Lucidarme J, Findlow J, et al. Potential coverage of the $4 C$ Men $B$ vaccine against invasive serogroup $B$ Neisseria meningitidis isolated from 2009 to 2013 in the Republic of Ireland. mSphere. 2018;3(4):e00196-18. PMID: 30135218. https://doi.org/10.1128/ mSphere.00196-18.

141. Kotelnikova O, Alliluev A, Zinchenko A, Zhigis L, Prokopenko Y, Nokel E, et al. Protective potency of recombinant meningococcal IgA1 protease and its structural derivatives upon animal invasion with meningococcal and pneumococcal infections. Microbes Infect. 2019. pii: S1286-4579(19)3002530025. doi: https://doi.org/10.1016/j.micinf.2019.02.003. PMID: 30797878. Epub ahead of print.

\section{Publisher's Note}

Springer Nature remains neutral with regard to jurisdictional claims in published maps and institutional affiliations.

Ready to submit your research? Choose BMC and benefit from:

- fast, convenient online submission

- thorough peer review by experienced researchers in your field

- rapid publication on acceptance

- support for research data, including large and complex data types

- gold Open Access which fosters wider collaboration and increased citations

- maximum visibility for your research: over $100 \mathrm{M}$ website views per year

At $\mathrm{BMC}$, research is always in progress.

Learn more biomedcentral.com/submissions 